\title{
AN HISTORICAL ACCOUNT OF UNEMPLOYMENT INSURANCE IN THE SOCIAL SECURITY ACT
}

\author{
EDWIN E. WITTE*
}

The Hrstorical Background

\section{Attempts at State Legislation}

Titles III and IX, the parts of the Social Security Act concerned with unemployment compensation, had behind them a long history of futile efforts to establish unemployment compensation through state legislation, without aid from the federal government.

The first unemployment insurance bill in any American state legislature was introduced in Massachusetts in I9I6. This was a measure modeled after the'limited British act of IgII, which never came to a vote. The second was the widely publicized Huber bill in the Wisconsin legislature of Ig2I, which was drafted by Dr. John R. Commons. ${ }^{1}$ This bill came within one vote of passing in the session in which it was first offered. Thereafter it was reintroduced, with some modifications, in each Wisconsin legislature until and including $193 \mathrm{r}$ but never again came even close to passage. In the 'twenties unemployment insurance bills were introduced also in Massachusetts, New York, Connecticut, and Minnesota. Throughout this period interest in the problem of protecting industrial workers against the hazards of unemployment was noticeably increasing and a considerable number of voluntary unemployment insurance plans were launched by progressive employers or under trade agreements. ${ }^{2}$

The great depression which began in 1929 enormously increased public interest in unemployment insurance. This was manifested in the introduction in I93I of unem-

* A.B., 1909, Ph.D., 1916, University of Wisconsin. Professor of Economics, University of Wisconsin. Executive Director of the Committee on Economic Security, 1934-1935. Special Agent, United States Commission on Industrial Relations, I914-1915; Secretary, Industrial Commission of Wisconsin, 1917-1922; Chief, Wisconsin Legislative Reference Service, I922-r933; Acting Director, Unemployment Compensation Division, Industrial Commission of Wisconsin, 1934. Member and Secretary, Wisconsin Interim Committee on a Retirement System for State Employees, 1929-1931. Author, The Government in Labor Disputes (1932) and of numerous articles in the fields of social insurance, labor law, and labor legislation.

${ }^{1}$ In most accounts of the history of unemployment compensation in the United States, the Wisconsin bills of the 'twenties are treated as if they provided for individual employer accounts, as does the present Wisconsin law. This was not the case. All Wisconsin bills prior to I931 provided for a pooled fund, without individual employer accounts, but with varying rates of contributions. The essential provisions of the Huber Bill are given in Forsberg, Selected Articles on Employment Insurance (I926) 124-127.

'The most comprehensive treatise on these experiments is STEWART, UNEMPLOYMENT BENEFITS IN THE United States (1930). A study of the more recent experience with voluntary plans was made for the Committee on Economic Security by Miss Constance A. Kiehel. 
ployment insurance bills in no less than $x 7$ state legislatures and in the creation of interim committees to study this problem in six states in 193r. In the next year, reports in favor of the immediate enactment of unemployment compensation laws were made by four of these commissions, a municipal commission of the city of Baltimore, and the Interstate Commission on Unemployment, which was organized at the instance of Governor (now President) Roosevelt and was composed of appointees of the governors of six leading eastern industrial states. ${ }^{3}$ In June of this year the Democratic National Platform pledged the party which won the national election to support "unemployment insurance under state laws"; and in November the American Federation of Labor, previously opposed to unemployment insurance, reversed its position.

In 1933, 65 unemployment compensation bills were introduced in 24 states; and in I934, 2I bills in five of the nine states whose legislatures met in regular sessions in this year. In these two years there were unemployment insurance study commissions in eleven states, ten of which made favorable reports. In seven states in 1933 and one state in 1934, unemployment compensation bills passed one house of the legislature, only to fail in the other. Wisconsin alone enacted an unemployment compensation law, doing so in February, 1932. This Wisconsin law was the only concrete result of all the numerous endorsements of unemployment compensation and the years of effort for the enactment of state legislation.

Doubtless there were many reasons for this record of almost complete failure; but the factor which overshadowed all others was the fear encountered in every state that enactment of an unemployment insurance law would place a heavy burden on employers of the state which would handicap them in competition with employers from states not having such a law. ${ }^{4}$

\section{Proposals for Federal Legislation}

The first time that unemployment insurance came before Congress was in $x 916$ in the form of a resolution by Representative Meyer London, New York Socialist, for the creation of a committee to draft a bill for a national unemployment insurance fund. ${ }^{5}$ Thereafter this subject did not again come up until the Senate in 1928 adopted a resolution of Senator Couzens for an investigation by the Committee on Labor and Education of the entire subject of unemployment insurance. This investigation was conducted by a sub-committee, which, after hearings, reported that any legislation for compulsory unemployment insurance was premature, although it favored the voluntary establishment of unemployment reserve funds by employers. ${ }^{6}$

\footnotetext{
3 The most convenient source of information for all developments affecting unemployment insurance throughout this period is the American Labor Legislation Review.

'For a clear statement that this was the major dificulty, see the testimony of Dr. I. M. Rubinow in the Hearings on Unemployment Insurance before a sub-committee of the House Ways and Means Committee, 73d Cong., 2d Sess. (1934), p. I90.

${ }^{5}$ H. Res. 159, 64th Cong., Ist Sess. (19r6).

${ }^{\circ}$ Sen. Rep. No. 2072, 70th Cong., 2d. Sess. (1928).
} 
Another investigation was conducted by a select committee, created in the spring of I93I under a resolution offered by Senator Wagner. This committee, composed of Senators Hebert, Glenn, and Wagner, after personal investigation of the European systems, reported in the spring of $193^{2}$ endorsing compulsory unemployment compensation legislation but concluding that the federal government could do nothing in this field except through allowing credit against federal income taxes for contributions by employers to unemployment reserve funds. ${ }^{7}$ Several different bills for such credits were introduced by Senator Wagner but none of them ever came to a vote.

In February, 1934, Senator Wagner, jointly with Congressman Lewis of Maryland, offered a new bill to encourage the enactment of state unemployment compensation laws. ${ }^{8}$ This Wagner-Lewis bill went to the root of the difficulty blocking state legislation: the removal of the unfair advantage enjoyed by employers in states which do not have unemployment compensation laws. It did this through proposing the levy of an excise tax of five per cent of their payrolls upon all employers of ten or more persons (with some exceptions), against which an offset was to be allowed equal to the contributions of these employers to unemployment reserve funds established pursuant to a state law meeting standards prescribed in the federal act.

This bill was hailed with great enthusiasm by all advocates of unemployment insurance and endorsed in strongest terms, in hearings conducted before a subcommittee of the House Ways and Means Committee, by such leading specialists as Dr. I. M. Rubinow, Paul Douglas, Abraham Epstein, and John B. Andrews, as well as by William Green of the American Federation of Labor, a half dozen employers who had experience with voluntary unemployment reserves plans, and the Secretary of Labor, Frances Perkins. President Roosevelt in a letter to Chairman Doughton of the Ways and Means Committee, likewise, endorsed the bill in principle and expressed the hope that it would be passed before the close of the session. ${ }^{9}$ Nevertheless, the Wagner-Lewis Bill was not passed, nor even reported. The President himself did not include this bill in the list of "must" measures whose passage he demanded before the end of the session and it died with adjournment.

This outcome seems in part to have been attributable to the belief of some sincere supporters of unemployment insurance that the proposed bill could be improved through further study. In particular, there were many who believed it to be desirable that Congress should prescribe more in detail what the state unemployment compensation laws must contain, to insure uniformity throughout the country. There was much sentiment also for giving to the federal government control over the investment and liquidation of the unemployment reserve funds in order to assure that such funds would operate toward the stabilization of industry, rather than the reverse. Finally, there were many who believed that the time was ripe for a more comprehensive program for economic security than unemployment insurance alone.

\footnotetext{
${ }^{7}$ Sen. Rep. No. 964. 72d Cong., Ist Sess. (I932).

${ }^{8}$ H. R. 7659, 73d Cong., 2d Sess. (1934). The hearings on this bill were conducted in March, 1934, and published in the usual form.

- New York Times, March 24, 1934 .
} 
This view was adopted by the President. In a special message to Congress on June $8,1934{ }^{10}$ without mentioning the pending Wagner-Lewis Bill, the President, in effect, promised the country that he would present to the new Congress which would convene in January a program for "furthering the security of the citizen and his family through social insurance," which would "provide at once security against several of the great disturbing factors in life-especially those which relate to unemployment insurance and old age."

\section{Preparation of the Economic Security Bill}

In accordance with this message, the President in an Executive Order, dated June 28, I934, created the Committee on Economic Security. ${ }^{11}$ This Committee was constituted of the Secretary of Labor as chairman, the Secretary of the Treasury, the Attorney General, the Secretary of Agriculture, and the Federal Emergency Relief Administrator. It was directed to "study problems relating to economic security of individuals" and to "report to the President not later than December I, 1934, its recommendations concerning proposals which in its judgment will promote greater economic security." To assist the Committee, this executive order provided for the appointment by it of a Technical Board on Economic Security, composed of persons in the government service who had special knowledge of the problems to be dealt with, and of an Executive Director and a staff. It also provided for an Advisory Council on Economic Security, to be constituted of citizens not in the government service to be subsequently appointed by the President, which was to "assist the Committee in the consideration of all matters coming within the scope of its investigations." For the expenses of this investigation, $\$ 85,000$ was set aside from emergency relief funds, a sum later increased to a total of approximately $\$ 125,000$.

The contemplated study was actually begun a month after the issuance of the executive order. Arthur J. Altmeyer, Second Assistant Secretary of Labor, was named Chairman of the Technical Board; Thomas H. Eliot, Associate Solicitor of the Department of Labor, Counsel of the Committee; and the author of this article, Executive Director and Secretary. Twenty persons altogether were named as members of the Technical Board. ${ }^{12}$ All of these members devoted a large part of their time for several months to this work, some of them nearly all of their time, although continuing on the payrolls of their respective departments. This Board functioned through meetings of its entire membership, through sub-committees, and through counsel and assistance given by individual members to the staff and the Committee on Economic Security. It made no final, formal report, but representatives of the

${ }^{10} \mathrm{H}$. Doc. No. 397, 73d Cong., 2d Sess. (1934). $\quad{ }^{11}$ Exec. Order, No. 6757.

${ }^{12}$ Complete lists of the membership of the Technical Board, the Advisory Council, and all other advisory committecs are given in the Report to the President of the Committee on Economic Security. Sce also Hearings before the House Committee on Ways and Means on H. R. 4120 (Economic Security Act) 74th Cong., Ist Sess., (Jan. 21-Feb. 12, 1935) at pp. 60, 62; Hearings before the Senate Finance Committec on S. II30 (Economic Security Act) 74th Cong., Ist Sess. (Jan. 22-Feb. 20, I935) appendix. (The reports of these hearings will hereafter be cited as "House Hearings" and "Senate Hearings" respectively.) 
Board attended all meetings of the Committee on Economic Security and were in constant touch with its members.

A staff of specialists not connected with the government service was assembled by the Executive Director and the Technical Board during the month of August. Studies were initiated on all major phases of the problems of social security. These studies were not directed primarily toward the collection of new information, but toward the summation and evaluation of the vast amount of data available in all of these fields.

More attention was given by the staff and the Technical Board to unemployment insurance than any other subject. The Technical Board created a committee on unemployment insurance ${ }^{13}$ which included several of the most eminent students of this institution in the entire country. The staff, likewise, embraced a goodly percentage of the specialists in this field and able statisticians and actuaries. ${ }^{14}$ Studies made included estimates of unemployment in the last complete business cycle and of the probable contributions and benefit costs under varying plans for unemployment compensation; the experience of foreign countries with unemployment insurance; the operation of voluntary systems in this country; the economic effects of unemployment reserves and the handling and investment of reserve funds; the administration of unemployment insurance; alternatives to unemployment insurance; and various technical questions. These staff studies finally culminated in reports which were presented to the Committee on Economic Security and later made available to the Congressional committees. ${ }^{15}$

19 This staff was headed by Dr. Bryce Stewart, Director of Research, Industrial Relations Counselors, Inc., New York, with Merrill G. Murray, Director, Minnesota State Employment Service, as his principal assistant. Associated with them were some twelve research assistants, several of whom had written extensively on unemployment insurance. William R. Williamson, Actuary, Travellers Insurance Company; Fred S. Jahn, now with the National Industrial Conference Board; and Robert R. Nathan, now with the United States Department of Commerce, headed the actuarial and statistical staff. A special committee of actuarial consultants was created by the Committee on Economic Security to check all actuarial methods and calculations. These actuarial consultants were Professor James W. Glover, University of Michigan; Professor Henry L. Rietz, University of Iowa; Professor A. L. Mowbray, University of California; and M. A. Linton, President, Provident Mutual Life Insurance Company. The study of the economic effects of unemployment reserve funds and their administration was made by O. S. Powell, Federal Reserve Bank of Minneapolis, and Allan R. Sweezy, Harvard University, under the direction of a special committee of the Technical Board consisting of Messrs. Riefler, Hansen, and Viner.

"The members of the sub-committee on unemployment insurance were Dr. Alvin H. Hansen, Chairman of the Economics Department and Director of the Employment Stabilization Research Institute of the University of Minnesota, then Chicf Economic Analyst of the Department of State, Chairman; Dr. Wm. M. Leiserson, Chairman of the National Mediation Board and former chairman of the Ohio Unemployment Insurance Commission; Thomas H. Eliot, Counsel of the Committee on Economic Security; Dr. Jacob Viner, internationally known economist of the University of Chicago, at the time Advisor to the Secretary of the Treasury; and E. Willard Jensen, Executive Secretary, Business Advisory Council, Department of Commerce.

The Executive Committee of the Technical Board consisted of Dr. Winfield S. Riefler, Executive Director, Central Statistical Board, Chairman; Dr. Viner; Corrington T. Gill, Assistant Federal Emergency Relief Administrator; Alexander Holtzoff, Assistant to the Attorney General; and H. R. Tolley, Assistant Administrator, Agricultural Adjustment Administration.

${ }^{15} \mathrm{~A}$ list of the more important of these studies is given in the Senate Hearings, pp. 323-324. A summary of the factual material in these reports is expected to be published in the near future by the Social Security Board. 
From the outset, the Committee on Economic Security indicated that it desired not merely a summary of all available information on the subject of unemployment insurance, but also the advice of the Technical Board and the specialists in its employ on the legislation, if any, which it should recommend. To this end, conferences were held on an average of twice a week, which were participated in by the executive and unemployment insurance committee of the Technical Board, the chairman of the Board, the Executive Director and Counsel of the Committee and all of its principal staff members.

A majority of the members, both of the Technical Board and the staff, originally favored a strictly federal system of unemployment insurance. It was recognized by all that a federal system would have many advantages, particularly those of uniformity throughout the country. Accordingly, an attempt was made to work out the details of a federal system, but it was found impossible to reach any agreement regarding details. In the end the members of the Technical Board, nearly unanimously, concluded that a federal system of unemployment compensation is impractical in this country, under existing conditions.

The same conclusion was reached regarding a unique suggestion made in these conferences for a coopperative federal-state system, in which the federal government would collect all contributions and prescribe all major conditions for unemployment insurance legislation, but would leave the actual administration to the states and return to them the contributions collected from their employers (and employees). This proposal, likewise, was most thoroughly explored because it seemed a method through which uniformity in unemployment insurance legislation could be secured through federal action. But this "subsidy" plan also encountered disagreements over the conditions to be imposed upon the states. In the end, the Technical Board reached the conclusion that, in the absence of experience with unemployment insurance in this country, it is desirable to allow wide latitude for experimentation and recommended to the Committee on Economic Security a plan for federal legislation on this subject similar to that of the Wagner-Lewis Bill in the preceding Congress. Some members of the staff dissented, continuing to advocate an exclusively federal system of unemployment compensation, or, if this was not deemed advisable, the "subsidy" plan, with the federal government prescribing in detail the legislation the states would have to adopt to be entitled to a return of the taxes collected from their employers.

Early in November the President appointed the Advisory Council on Economic Security. The twenty-three members of this Council were all eminent citizens drawn from private life, with President Frank P. Graham of the University of North Carolina as chairman. The Council held its first meetings in the second week in November and further meetings in the last week in November and second week in December. Its first series of meetings was devoted to a preliminary consideration 
of possible alternative courses of action; the later meetings to an attempt to formulate its own recommendations.

Like all other groups, the members of the Advisory Council differed on the details of the federal legislation which ought to be adopted on the subject of unemployment insurance. Major differences developed over the type of federal law to be recommended, contribution rates, contributions from general tax revenues, and compulsory employee contributions. Nine members voted in favor of the "subsidy," seven in favor of the "Wagner-Lewis" type of law, with six not voting or absent; a majority opposed employee contributions, but six members filed a supplemental report to the contrary; and five other members a supplemental report urging higher contribution rates. Yet all members of the Advisory Council united in a report, ${ }^{16}$ in which they outlined, fairly and ably, the arguments pro and con on each point on which there were differences and concluded:

"All of the members recognized that each type of federal law has distinct merits, and wish their votes to be interpreted not as necessarily opposing either type of law, but as preferring one to the other."

All were agreed that federal legislation on unemployment insurance was desirable at the coming session of Congress and that federal action is necessary to enable the states to pass unemployment compensation laws. ${ }^{17}$

${ }^{10}$ The complete text of the Report of the Advisory Council and of all supplementary statements by groups of members of the Council which were formally filed with the Committee on Economic Security is published in the Senate Hearings, pp. 226-237, 324-326, 331-332, and in the House Hearings, pp. $871-893$.

${ }^{17}$ The position of the Advisory Council appears clearly from the opening paragraphs of the part of its report dealing with unemployment compensation:

"All members of the Advisory Council join with the President in holding that legisiation for unemployment compensation, on as nearly a Nation-wide basis as possible, should be enacted this winter.

"We support his statement to the National Conference on Economic Security that 'unemployment insurance must be set up with the purpose of decreasing rather than increasing unemployment." While we believe that the States should be permitted a large freedom in choosing the type of plan they establish, we strongly recommend that the Committee on Economic Security, in considering Federal legislation, and that the States in considering State legislation, keep in mind these two principal objectives:

(I) The plan should promote security by providing compensation for workers who are 'laid off.'

(2) The plan should serve as an incentive to employers to provide steady work and to prevent unemployment.

"We regard it as settled that unemployment compensation at this time should be developed along Federal-State lines. In this coöperative undertaking the Federal Government must assume the leadership. It should make it easier for the States to act by removing those disadvantages in interstate competition which are always raised against purely State legislation that involves costs to industry. This knot should be cut by requiring industries in all States (whether the States enact unemployment compensation laws or not) to make uniform pay-roll contributions. The Federal government should enact a law prescribing minimum standards, and should actively assist the States in preparing necessary State legislation and in getting their plans into operation. The Federal Government should set up an administrative authority, and as suggested by the President, should assume responsibility for the safeguarding of all unemployment reserve funds and use these funds to promote stabilization.

"The States for their part must assume responsibility for State administration. Unemployment compensation benefits must necessarily be locally administered and no large bureaucracy in Washington need be created if this principle is observed. Subject to necessary minimum standards prescribed in the Federal law, wide latitude should be allowed the States to experiment with respect to the particular form and provisions of the unemployment compensation laws which they may enact. Such laws should, however, be completely divorced from relief." 
The Committee on Economic Security began its consideration of the recommendations to be made to the President several weeks before the Advisory Council made its formal report, but did not reach any final decisions until Christmas. In its deliberations it gave consideration not only to the recommendations of the Advisory Council, the Technical Board, and the staff members, but to many suggestions from outside sources. These included the views expressed by the President in his address to the National Conference on Economic Security, ${ }^{18}$ the complete verbatim record of all addresses and discussion at this Conference, the recommendations of a group of specialists attending it, and a Memorandum on Unemployment Insurance by the Committee on Industrial Relations of the Business Advisory and Planning Council of the Department of Commerce, which conducted an independent study of this subject of several months' duration, as well as numerous suggestions made by private individuals and organizations.

The recommendations from all of these sources were given consideration, but, as they were conflicting, they could not all be adopted. In line with most of the recommendations, the Committee concluded that a federal system of unemployment insurance was out of the question. As between a "subsidy" type of federal law and the "Wagner-Lewis" plan, it decided in favor of the latter, primarily because it concluded that the federal government should not attempt to regulate in detail what the states should include in their unemployment compensation laws. It recognized the need for uniformity in state legislation, but felt that under the Constitution, such uniformity must be brought about through the voluntary action of the states (which, it felt, should be encouraged and promoted by the federal government), not through federal dictation. It included in its report recommendations to the states regarding desirable provisions in state unemployment compensation laws, but recommended that the federal legislation be confined to the levy of a tax on employers throughout the country, measured by payrolls, against which an offset is to be allowed for

\footnotetext{
${ }^{18}$ The National Conference on Economic Security was beld at Washington on November 14, 1935, under the auspices of the Committee on Economic Security. To this conference there were specially invited several hundred outstanding leaders of industry, labor, and agriculture, and substantially all persons not connected with the work of the Committee who had written articles on any phase of the problems of social security, including some persons from every state in the Union. Nearly all persons specially invited attended the conference, as did many others, all sessions of the conference being open to the public. The conference divided into sections devoted to each of the major fields of social security, with specialists not connected with the Committee and known to hold opposite views as leaders of the discussion. The entire conference was addressed by the President, who in his speech repeated his promise that he would present to the incoming Congress a comprehensive legislative program on economic security including unemploy. ment insurance and old age pensions, but stating that he had not yet decided whether the time was opportune for old age insurance. On unemployment insurance he again expressed his conviction that this institution should be developed as a coöperative federal-state undertaking, with the administration vested in the states with wide latitude allowed to them for experimentation, but with the investment and liquidation of the reserve funds within control of the federal government. He further urged that unemployment insurance should be completely divorced from relief, should be financed by contributions not (general) taxes, and should encourage the stabilization of employment. The President's address and all of the more general speeches at the conference were published by the Committee on Economic Security in a pamphlet entitled, "Security" (November, 1935), and a complete verbatim record of all proceedings was furnished all members of the Committee on Economic Security.
} 
contributions made under state unemployment compensation laws, with even less restrictions than were included in the Wagner-Lewis Bill in the preceding Congress. ${ }^{10}$ In only two respects did it deem restrictions going beyond mere definitions of unemployment compensation to be necessary: it recommended that the investment and liquidation of unemployment reserve funds be centralized in the federal government, and that, if a state adopts an employer reserve type of law, it must require all employers to contribute at least one per cent on their payrolls to a central pooled fund, from which unemployed workmen might draw benefits when the accounts of their employers are exhausted.

As has been stated, the Committee reached a unanimous decision regarding the report to be made to the President just before Christmas and at that time informally presented its recommendations to the President. Thereafter, the formal report of the Committee was drafted and a bill in accordance with the Committee's recommendations prepared by its Counsel, with assistance from Treasury officials, Congressional draftsmen, and members of Congress. The completed report was presented to the President on January 15, $1935 .^{20}$

\section{Congressional Consideration}

The President transmitted the Report of the Committee on Economic Security to Congress in a special message on January 17,1936 , in which he recommended legislation in accord with the suggestions of the Committee, urging prompt action by Congress because the recommended program necessitated state, as well as federal, legislation, and most state legislatures were then in session but would adjourn within a few months. ${ }^{21}$

${ }^{10}$ The essentials of the program recommended appear clearly in the summary of its recommendation included in its Report (page 4):

"We believe that the states should administer unemployment compensation, assisted and guided by the federal government. We recommend as essential the imposition of a uniform pay-roll tax against which credits shall be allowed to industries in states that shall have passed unemployment compensation laws. Through such a uniform pay-roll tax it will be possible to remove the unfair competitive advantage that employers operating in states which have failed to adopt a compensation system enjoy over employers operating in states which give such protection to their wage earners.

"We believe also that it is essential that the federal government assume responsibility for safeguarding, investing, and liquidating all reserve funds, in order that these reserves may be utilized to promote economic stability and to avoid dangers inherent in their uncontrolled investment and liquidation. We believe, further, that the federal act should require high administrative standards, but should leave wide latitude to the states in other respects, as we deem experience very necessary with particular provisions of unemployment compensation laws in order to conclude what types are most practicable in this country."

${ }^{20}$ This report was published in pamphlet form by the Committee on Economic Security and as a Congressional Document in both houses of Congress. It was also incorporated in the hearings on the Economic Security Act conducted by the House Ways and Means Committee and the Senate Finance Committee.

"I On unemployment compensation the President recommended specifically:

"With respect to unemployment compensation, I have concluded that the most practical proposal is the levy of a uniform federal payroll tax, ninety per cent of which should be allowed as an offset to employers contributing under a compulsory state unemployment compensation act. The purpose of this is to afford a requirement of a reasonably uniform character for all states coöperating with the federal government and to promote and encourage the passage of unemployment compensation laws in the states. The ten per cent not thus offset should be used to cover the costs of federal and state administration of this 
Bills incorporating the recommendations of the President and the Committee on Economic Security were presented on the same day by Senator Wagner, Representative Doughton, and Representative Lewis..22 These bills were referred in the House to the Ways and Means Committee and in the Senate to the Finance Committee, and in both houses hearings were begun almost immediately. ${ }^{23}$

A large part of the entire testimony was devoted to unemployment compensation. Both committees examined at length the chairman and other members and representatives of the Committee on Economic Security and received testimony from a number of members of the Technical Board and the Advisory Council. They also received testimony from labor union officials, industrialists, and prominent citizens in support of the bill, and other testimiony in opposition or criticism. Witnesses criticized the bill both as being too conservative and too radical. Some witnesses opposed any action by the federal government on unemployment compensation, while others favored the radical Lundeen Bill. ${ }^{24}$ In between were a considerable number of people who expressed approval generally of the Administration bill, but urged that more standards should be written into the Federal Act to which the state unemployment compensation laws must comply. Almost without exception, these witnesses who urged the inclusion of more standards in the Federal Act also expressed themselves in favor of a "subsidy" type of law.

After conclusion of its hearings, the House Ways and Means Committee at once began consideration of the bill in executive sessions, which ran altogether to nearly twenty meetings. The Committee decided early to completely redraft the proposed bill and made numerous changes in policy. In the end, an entirely new bill emerged, which was reported to the House for passage on April 5, with eight of the twentyfive members of the Committee dissenting as to some parts of the bill, but approving of the two titles dealing with unemployment compensation. ${ }^{25}$

broad system. Thus, states will largely administer unemployment compensation, assisted and guided by the federal government. An unemployment compensation system should be constructed in such a way as to afford every practicable aid and incentive toward the larger purpose of employment stabilization. This can be helped by the intelligent planning of both public and private employment. It also can be helped by correlating the system with public employment so that a person who has exhausted his benefits may be eligible for some form of public work as is recommended in this report. Moreover, in order to encourage the stabilization of private employment, federal legislation should not foreclose the states from establishing means for inducing industries to afford an even greater stabilization of employment."

${ }^{2}$ S. Ir $30 ;$ H. R. 4 r20, 74th Cong., Ist. Sess. (I935).

23 These hearings were conducted by both committees before their entire membership, and with nearly all members present at all times. In the House the hearings lasted from January 2 I to February 12, with sessions on practically every intervening working day, and meetings frequently both forenoons and afternoons. In the Senate, the hearings ran from January 22 to February 20, with somewhat less pressure to bring them to a conclusion, as it was agreed that being a finance measure, this bill should first be acted upon in the House of Representatives. The hearings in the House were published in a volume of $1 \mathrm{III}_{\mathrm{I}}$ pages, while those of the Senate Committee ran to 1354 pages.

${ }^{24}$ H. R. 2827 , 74th Cong., Ist Sess. (1935).

25 The new bill was H. R. 7260. In this bill even the title was changed from "Economic Sceurity $\Lambda$ ct" to "Social Security Act." The report to the House was made in H. Rep., No. 615, 74th Cong., 1st Sess. (1935). The majority report contains the following lucid explanation of the purposes of Titles III and IX:

"The bill permits the states wide discretion with respect to the unemployment compensation laws they 
This bill differed less radically from the original bill with respect to unemployment compensation than in the provisions relating to old-age security, but there were some essential differences. These included the elimination of some of the "standards" for state legislation, particularly the requirement for the selection of all personnel connected with the administration of unemployment compensation on a merit basis, and restriction of the coverage of the federal tax, but also the striking out of all provisions permitting states to have any type of law other than a pooled fund with equal contribution rates from all employers and of all provisions according a lower rate of tax to employers who have stabilized employment.

The Social Security Bill came up for consideration in the House of Representatives on April Ir, under a rule permitting complete freedom of amendment. This was the first major measure considered under such a wide open rule in several Congresses. Debate lasted until April I9. While the greatest interest clearly was in old-age security, nearly a dozen amendments were offered to the unemployment compensation titles, none of which, however, was adopted or received any considerable vote. On April x9, the House passed the bill by a vote of 37 I Yeas to 33 Nays, the overwhelming majority of the members of all parties supporting the measure.

Following passage in the House, the Social Security Bill came up for consideration in executive sessions of the Senate Finance Committee in the first weeks in May, this committee devoting practically all of two weeks to such consideration. A report favorable to passage, with amendments, was filed on May 20. ${ }^{26}$ The major amend-

may wish to enact. The standards prescribed in this bill . . . are designed merely to insure that employers will receive credit against the federal pay-roll tax only for payments made under genuine unemployment compensation laws.

"Yet the federal government, under this bill, has important functions to perform in order to make it possible for the states to have unemployment insurance laws and to facilitate their operation. It equalizes competitive conditions through the imposition of the employment excise tax provided for in Title IX. The bill further provides that the Social Security Board, which is created in Title VII to administer all parts of the social security program other than aids coming within the scope of operation of existing bureaus, shall have the duty of studying and making recommendations with respect to the broad problems of economic security. This Board will be able to render important actuarial and scientific services to the states in connection with their unemployment insurance systems. In Title III financial aid is given the statcs by the federal government to defray their costs in administering unemployment insurance. Finally, the federal government is to handle all unemployment reserve funds, in a trust account in the United States Treasury for the bencfit of the states to which they belong.

"This last provision will not only afford maximum safety for these funds but is very essential to insure that they will operate to promote the stability of business rather than the reverse."

The minority stated that the purposes of this part of the bill are "commendable," but doubted whether they "will result in national benefit at this time." It concluded:

"However, we favor the principle of unemployment insurance. These titles of the Bill aid those states desiring to establish such insurance, and therefore we resolve all doubts in favor of this legislation."

$\approx$ Sen. Rep. No. 628 , 74th Cong., Ist Sess. (1935). In explanation of the titles dealing with unemployment compensation, the Committee said (p. 12):

"This bill does not set up a federal unemployment compensation system. What it sceks to do is merely" to make it possible for the states to establish unemployment compensation systems and to stimulate them to do so. This objective is carried out through grants-in-aid to the states (in Title III) for the administration of unemployment compensation laws and through the imposition of a uniform pay-roll tax on employers 
ments relating to unemployment compensation were the restoration of complete freedom to the states with reference to the type of unemployment compensation law they should adopt, without any restrictions, and the inclusion of provisions to encourage the stabilization of employment.

The Senate debated the Social Security Bill from June $I_{4}$ to June 19, with no intervening business of any importance. As in the House, there was little disagreement over the provisions relating to unemployment compensation. All of the amendments proposed by the Finance Committee were adopted without a roll-call vote, and on June $x$, the Bill was passed with 76 Yeas and but 6 Nays.

Then followed a long period in which the two houses tried to compromise their differences. The amendments affecting unemployment compensation proved relatively easy of adjustment, but for a long time it was impossible to secure any agreement upon the "Clark Amendment" to Title II (old-age benefits). Finally the Clark Amendment was dropped with an agreement for the appointment of a joint committee to report on this subject at the next session of Congress. The Bill thereafter had easy sailing, the conference committee's report being adopted in both houses without even a roll-call vote, in the House on August 8 and in the Senate on August 9. Then on August 14, the President approved the Social Security Act, which became law immediately. 27

\section{The Enacted Law}

Throughout the history of the unemployment compensation provisions of the Social Security Act, there was general agreement regarding the necessity for federal legislation. It was recognized by everyone who believed in the desirability of unemployment insurance that little headway could be made unless employers in all states would be subject to the same (or substantially the same) costs, whether their respective states enacted unemployment insurance laws or not. This is the major objective of the tax levied in Title IX, although that Title will also yield considerable revenue to the federal government, of which it stands in great need at the present time.

In its final form, the Social Security Act neither sets up a federal system nor provides for federal regulation of unemployment insurance. This act merely seeks to make it possible for the states to pass unemployment compensation laws and to induce them to do so. It makes it the duty of the Social Security Board to give assistance to the states in the establishment and administration of unemployment compensation laws, but gives the Board no dictatorial powers whatsoever. The states are free to adopt any type law they wish. Congress eliminated the restriction

(in Title IX) against which a credit is allowed for contributions made by them to unemployment compensation funds set up pursuant to state law.

"Except for a few standards which are necessary to render certain that the state unemployment compensation laws are genuine unemployment compensation acts and not merely relief measures, the states are left free to set up any unemployment compensation system they wish, without dictation from Washington."

" Public, No. 271, 74th Cong., Ist Sess. (1935). 
upon laws of the individual employer account type which the Committee on Economic Security recommended. It also eliminated all provisions under which the Social Security Board might have exercised any control over the personnel concerned with the administration of unemployment insurance. The Federal Act leaves to the decision of the states all questions relating to contributions and benefits; in fact, practically everything that is customarily included in unemployment compensation laws.

There are, indeed, in Section 903 (a), six conditions to which state laws must conform in order to be recognized for tax credit purposes under Title IX. These conditions, however, are, in the main, merely definitions of a genuine unemployment compensation act, not an attempt to secure uniformity throughout the country. This will be clear to anyone who will compare the multitude of provisions in any of the unemployment insurance laws which have been passed in this country with these conditions for the approval of state laws. Further clear proof to the same effect is that the Social Security Board has approved nine of the ten state laws which to date have been enacted in this country (the tenth law having not yet been submitted for approval), although these laws differ widely in their provisions.

The one condition which is not merely a definition of a genuine unemployment compensation act is the requirement that all contributions must be deposited in the Unemployment Trust Fund which is established in the United States Treasury. This is not a necessary provision of any unemployment compensation law, but a condition which was considered essential to the safety of the reserve funds and their management in such a way as to promote business stability. The promotion of business stability is a responsibility of the federal government arising out of its exclusive control of the currency. In inserting this condition in Section 903 (a), the federal government did no more than to insure that its efforts to maintain stability will not be set at naught through the creation, investment, and liquidation of large reserve funds over which it has no control. This provision does not interfere with complete state control over unemployment compensation and involves no impairment of states' rights.

Titles III and IX of the Social Security Act represent the fulfillment of the platform pledge on which the present Administration was elected of "unemployment insurance under state laws." Experience prior to the introduction of the Social Security Act conclusively demonstrated the impossibility of unemployment insurance without federal aid. Significantly, since then eight states and Congress, for the District of Columbia, have enacted unemployment compensation laws and, once Title IX is sustained, there is little reason to doubt that all, or nearly all, states will soon fall in line. The Social Security Act promises to become the instrumentality through which unemployment insurance will be attained on a nation-wide basis, and yet remain under state administration and state control. 